\title{
DINAMIKA KOMUNIKASI WANITA ARAB BERCADAR
}

\author{
Mutiah \\ Fakultas Ilmu Sosial dan Ilmu Politik, Jurusan Ilmu Komunikasi \\ Universitas PGRI Ronggolawe Tuban, Jawa Timur - 58315 \\ Jln. Manunggal no 61, Tuban, Hp, 085331345283 \\ email :mumutamron@yahoo.co.id \\ Naskah diterima tanggal 28 Mei 2013, disetujui pada tanggal 24 Juni 2013
}

\section{COMMUNICATION DYNAMICS OF VAILED ARAB WOMEN}

\begin{abstract}
Abstrack
This study focuses on the authentic appearance of Arab women who wear the veil, which is the veil itself is a cultural dress in Saudi Arabia. The study purpose to understand the meaning of cadar itself and know the managing impression that accured. The research use qualitative methode with fenomenology approach. In this study there were 11 informants who are willing to articulate their experiences openly. Generally, researcher obtained a spontaneous statement so the data obtained naturally. The meaning of wearing the veils that they construct by them self reduced into three categories. Wearing the veil as obeydiant of woman muslim, an honour and family tradition. These categories is influenced by situational factors. This research ultimately shows and understand the interaction and communication that occurs within communities of Arab women who wear veils itself and the interaction that occurs with the surrounding community, and nuances of the place of ethnic identity when interaction takes place.
\end{abstract}

Keywords : communication dynamic, vailed Arab women, ethnic identity, dramaturgi.

\begin{abstract}
Abstrak
Penelitian ini menitikberatkan pada penampilan otentik wanita Arab yang mengenakan cadar, yang notabene cadar sendiri adalah pakaian budaya di Arab Saudi. Tujuan penelitian ini untuk mengetahui makna cadar bagi wanita bercadar itu sendiri dan mengetahui pengelolaan kesan yang terjadi dalam komunitas wanita bercadar tersebut. Metode yang digunakan adalah metode kualitatif dengan pendekatan fenomenologi. Dalam penelitian ini terdapat 11 informan yang bersedia mengartikulasi pengalamannya secara terbuka. Umumnya penulis memperoleh sebuah pernyataan yang spontan sehingga didapat data yang natural. Makna cadar yang mereka konstruksi, penulis reduksi menjadi tiga kategori, yaitu cadar sebagai kewajiban, cadar sebagai kehormatan dan cadar berawal dari tradisi keluarga yang ketiga kategori ini sangat dipengaruhi oleh faktor situasional. Penelitian ini memperlihatkan dan memahami interaksi dan komunikasi yang terjadi dalam komunitas wanita Arab yang mengenakan cadar itu sendiri maupun interaksi yang terjadi dengan masyarakat sekitar, terjadi nuansa-nuansa identitas etnik ketika interaksi tersebut berlangsung.
\end{abstract}

Kata kunci: dinamika komunikasi, wanita Arab bercadar, identitas etnik, dramaturgi. 


\section{PENDAHULUAN}

Di tengah-tengah perjalanan di kota Nantes, seorang wanita muslimah Perancis ditangkap polisi saat ia mengendarai mobil dengan mengenakan cadar. Wanita muslimah yang umurnya sudah mencapai 31 tahun itu ditahan karena pakaiannya melanggar aturan standar keselamatan yang harus ia kenakan saat mengendarai mobil. Dengan memakai cadar dikhawatirkan dapat menggangu penglihatannya sehingga dapat membahayakan. Namun, alasan itu dibantah. Saat mengendarai mobil wanita itu tidak menutup seluruh wajahnya, melainkan menyisakan matanya supaya dapat melihat. Dalam pengakuannya kepada televisi LCI, wanita tersebut mengaku didenda 22 Euro atau sekitar Rp290.000 akibat cadar yang ia kenakan saat mengendarai mobil (Anonim, 2010) .

Salah satu universitas di Kanada telah mengusir seorang mahasiswinya dari kelas karena ia mengenakan cadar. Mahasiswi tersebut bernama Aisyah, ia adalah seorang mahasiswi yang berumur 25 tahun. Ketika ia mengikuti mata pelajaran bahasa Prancis, ia diberi dua pilihan, membuka cadar atau keluar kelas tidak mengikuti pelajaran. (Anonim, 2010).

Di Indonesia, negara yang mayoritas penduduknya beragama Islam, yang notabene sudah tak asing lagi dengan keberadaan wanita Arab yang mengenakan cadarpun terjadi hal yang sama, walaupun tidak seekstrim di negara-negara Barat. Inilah problematika berpakaian yang paling kontroversial dan tak ada habisnya dalam perdebatan panjang di negara dunia, bahkan dapat dikatakan satu-satunya pakaian yang mendapat "perhatian" masyarakat dunia. Perhatian yang disinyalir menyederai hak asasi beragama.

Ilmu komunikasi dapat berkontribusi dalam memahami fenomena di atas, konteks komunikasi budaya menyatakan bahwa pakaian menjadi salah satu ciri yang paling otentik untuk mengidentifikasikan individu dari budaya tertentu. Selain itu, melalui pakaian dapat diperkenalkan atau disosialisasikan nilai budaya tersebut, bahkan lebih jauh lagi bentuk dan mode pakaian dapat dinilai sebagai barometer keimanan, atau ciri khas dari kelompok tertentu. Itu semua menunjukkan bahwa pakaian merupakan simbol dari keperibadian, pekerjaan, sistem kepercayaan (politik, filosofi, dan agama) ataupun status sosial seseorang.

Menjadi komunitas yang berbeda dari kebanyakan bukanlah hal yang mudah untuk dilakoni, tentu saja interaksi wanita Arab dengan menggunakan pakaian yang khas ini tidak selalu berjalan lancar. Kendati kehadiran wanita Arab yang mengenakan cadar ini sudah terbilang lama, perlakuan buruk yang mereka terima lewat penilaianpenilaian bebas dari masyarakat setempat, seperti gunjingan langsung, dianggap fundamentalis, fanatisme berlebihan terhadap agama, adat istiadat Arab yang tradisional, aneh atau bahkan perlakuan yang melibatkan fisik, seperti disiram ketika mereka melintas di tempat umum, pernah terjadi. Perlakuan yang buruk seperti diungkapkan di atas, setidaknya menunjukkan bahwa identitas diri dan simbol budaya agama inilah yang menjadi sinyal tersendiri untuk ditafsirkan secara berbeda dan begitu kompleks.

Melalui pakaian yang mereka kenakan, diduga sarat akan pertunjukan pengelolaan kesan dan identitasnya di luar lingkungan komunitasnya. Pakaian abaya yang dikenakan beberapa wanita Arab yang tinggal di Palembang ini jelas mewakili simbol bernuansa agama dan budaya. Bahkan simbol-simbol yang bernuansa agama yang dianggap sakral sekalipun tidak lepas dari tarikan simbol sosial sebagai kekhasan di balik pengelolaan kesan dalam kehidupan sehari-hari mereka.

Pengelolaan kesan dan kesadaran wanita keturunan Arab yang menggunakan cadar di Palembang, bahwa adanya perbedaan berinteraksi dalam komunitasnya dan masyarakat sekitar, diduga mengindikasikan adanya definisi situasi secara nyata sehingga menyadari akibatnya yang rata. Kesadaran inilah yang menurut Mead dalam Mulyana (2004) "merupakan inti diri dan sumber identitas, kesadaran ini adalah hubungan individu dengan lingkungannya sejauh 
lingkungan itu eksis bagi individu". Kesadaran wanita keturunan Arab di Palembang akan dirinya dan simbol yang menyertainya menunjukkan hubungan diri yang mengamati, mengetahui, dan merefleksi dunia sosial di lingkungannya.

Adanya perlakuan yang tidak menyenangkan, yang diterima komunitas wanita keturunan Arab yang mengenakan abaya dan niqab di Palembang, bisa jadi karena faktor ritual interaksi sosial dengan simbol agama dan budaya yang mereka kenakan belum dapat tampil sebagai fasilitas komunikasi dalam kehidupan sosial seharihari mereka.

Penelitian mengenai simbol identitas etnik, bukanlah fenomena baru dan asing. Setiap etnis yang tersebar di Indonesia membawa kekhasan dan keunikannya masing-masing, begitu juga yang terjadi pada warga keturunan Arab khususnya wanita Arab yang mengenakan abaya dan niqab, yang tersebar di Palembang.

Permasalahan yang akan dikaji dalam penelitian ini adalah simbol-simbol komunikatif yang diduga dimaknai bernuansa agama sekaligus budaya yang dikenakan wanita Arab, tidak sepenuhnya mampu dimaknai oleh masyarakat di Palembang, khususnya yang tinggal di sekitar kelurahan Tiga Belas Ulu, kecamatan Seberang Ulu Dua Palembang, sebagai isyarat kedudukan agama dalam tataran sosiokultural yang menjadi faktor deferensiasi yang paling nyata. Ketika perlakuan buruk terjadi, kondisi tersebut diduga mengisyaratkan bahwa cadar yang dikenakan wanita Arab memiliki makna tersendiri.

Inilah permasalahan yang menarik untuk diteliti. Topik ini akan menjawab dinamika komunikasi yang terjadi, sehingga dari sini akan memunculkan beragam alasan, motivasi, makna dari keteguhan mereka mengenakan cadar dan semua pengalaman mereka selama mengenakan cadar.

Permasalahan tersebut dapat diindentifikasikan ke dalam dua pertanyaan pokok sebagai berikut: bagaimana wanita Arab mengonstruksikan makna cadar oleh mereka sendiri? bagaimana pengelolaan kesan yang dilakukan wanita Arab bercadar lewat komunikasi verbal dan nonverbal ?

Adapun tujuan penelitian: ingin mengkaji makna cadar dikonstruksi oleh wanita Arab bercadar itu sendiri. Ingin mengkaji pengelolaan kesan wanita Arab bercadar lewat komunikasi verbal dan nonverbal.

Penelitian ini diharapkan dapat memberikan manfaat dalam pengembangan konsep dan pendekatan simbol yang berkaitan dengan identitas etnik warga keturunan Arab khususnya wanita Arab yang mengenakan abaya dan niqab, sebagai manusia simbolik yang cair dan dinamis. Selanjutnya dari hasil penelitian ini diharapkan dapat memberikan sumbangan berupa temuan-temuan dan ideide yang menambah khazanah kepustakaan yang berguna bagi aspek pengembangan ilmu khususnya bidang komunikasi.

Selain itu hasil penelitian ini dapat bermanfaat sebagai salah satu rujukan dalam menekan kemungkinan fenomena diskriminasi tersembunyi dari simbol agama dan simbol budaya yang masih belum bisa diterima secara utuh.

\section{LANDASAN KONSEP}

\section{Komunikasi}

Dinamika komunikasi merupakan proses komunikasi yang berlangsung terusmenerus yang menimbulkan perubahan di tata kehidupan masyarakat yang bersangkutan, di mana individu-individu menggunakan simbol-simbol untuk menciptakan dan menginterpretasikan makna dalam lingkungan mereka. Dinamika komunikasi wanita keturunan Arab yang menggunakan cadar di Palembang, tentu saja terlihat nyata melalui proses transmisi pesan budaya dan agama mengenai cadar secara turun temurun maupun interpretasi makna cadar dalam diri mereka sendiri.

Proses komunikasi yang berlangsung terus menerus ini mau tidak mau menimbulkan perubahan di tata kehidupan mereka. Mereka menjadi sadar bahwa cara mereka berpakaian akan memengaruhi ruang gerak dalam berkehidupan sosial khususnya dengan masyarakat pribumi. Karena itulah 
komunikasi juga dapat didefinisikan sebagai proses berbagi makna melalui perilaku verbal dan nonverbal. Segala perilaku dapat disebut komunikasi jika melibatkan dua orang atau lebih. Simbol dapat pula merepresentasikan suatu konsep atau gagasan yang lebih abstrak (Mulyana, 2008). Tentu perilaku yang diberi makna ini bukan sekedar simbol yang telah disepakati bersama melainkan juga tandatanda tertentu yang potensial untuk dimaknai seperti penampilan khas wanita Arab dengan menggunakan abaya dan niqab.

\section{Cadar atau Abaya dan Niqab}

Cara muslimah berpakaian, dan alasan mengapa mengenakan pakaian tersebut merupakan pernyataan budaya yang lain menyangkut peranan gender dalam budaya Islam. Kebanyakan wanita Islam mengenakan jilbab untuk menutup kepalanya dan abaya atau jubah yang dilengkapi dengan niqab sebagai pakaian untuk menutupi kulit dan wajah mereka. Alasan berpakaian seperti ini ditemukan dalam Alquran yang memerintahkan perempuan untuk "menutup perhiasan mereka" dan "mengenakan selubung sampai dada mereka", lebih jelasnya dapat dilihat dalam surat AlAhzab ayat 59 sebagai berikut:

"Hai nabi, katakanlah kepada istri-istrimu, anak-anak perempuanmu, dan istri-istri orang mukmin, "hendaklah mereka mengulurkan jilbab ke seluruh tubuh mereka" yang demikian itu supaya mereka lebih mudah untuk dikenal, karena itu mereka tidak diganggu. Dan Allah adalah Maha Pengampun lagi Maha Penyayang”

Terbagi dua pendapat mengenai, pakaian menurut syariat Islam, pendapat pertama mengatakan bahwa niqab (cadar) tidak termasuk syariat agama Islam, dan justru hanya adat istiadat Timur Tengah saja, bahkan secara tegas pendapat ini mengatakan bahwa niqab adalah adat bukan ibadah. Sementara jika merujuk pada jumhur salafiwahhabi, mempunyai dua qawl (pendapat) terkait hukum wajah perempuan. Qawl pertama menyatakan jika wajah adalah aurat. Sementara dalam qawl terakhir, Ibn Hanbal tidak menyatakan wajah sebagai aurat.
Kemudian disusul dengan ayat Alquran surat AnNur ayat 31:

"Hendaklah mereka menutup khimar atau kerudung ke dada mereka..."

Penegasan dalam ayat ini, khimar atau kerudung adalah apa yang dapat menutupi kepala, leher, dan sebagian dada tanpa menutupi muka. Batas bawah yang ditutup oleh kerudung adalah bagian kerah baju yang memperlihatkaan leher dan dada, menunjukkan bahwa ada perbedaan mengenai penutup kepala atau pakaian Islam dengan budaya Arab.

Pakaian abaya sendiri, secara umum merupakan pakaian yang dikenakan semua perempuan di Arab Saudi. Mengenakan niqab dan abaya sebagai wanita Saudi diwajibkan baik oleh hukum dan tradisi untuk memakai niqab. Menurut hukum Syariah Arab Saudi, pakaian wanita harus memenuhi persyaratan sebagai berikut: 1) Wanita harus menutupi seluruh tubuh mereka, tetapi mereka diizinkan untuk mengekspos mata salah satu atau kedua dalam kebutuhan; 2) Wanita harus mengenakan abaya dan niqab cukup tebal untuk menyembunyikan apa yang di bawahnya, dan abaya harus longgar. Wanita tidak boleh mengenakan pakaian berwarna cerah atau baju yang dihiasi sehingga mereka dapat menarik perhatian laki-laki (Mai, 2008).

Adapun di beberapa negara Islam, jilbab dikenal dengan beberapa istilah. Kalau di Iran disebut chador, pardeh di India dan Pakistan, milayat di Libya, abaya di Irak, charshaf di Turki, hijâb di beberapa negara Arab-Afrika seperti di Mesir, Sudan, dan Yaman. Hanya saja pergeseran makna hijâb dari semula yang berarti tabir, berubah makna menjadi pakaian penutup aurat wanita semenjak abad ke 4 H (Mai, 2008).

Abaya ini digunakan untuk melapisi pakaian biasa mereka saat mereka keluar dari rumah (berada di tempat umum). Abaya tradisional merupakan pakaian terusan lengan panjang berwarna hitam. Selain itu, wanita Saudi harus menutupi seluruh rambutnya ketika keluar rumah atau bertemu dengan orang yang bukan mahramnya.

Merupakan tuntutan agama Islam yang memerintahkan para muslimah untuk menutup aurat dari pandangan nonmahram 
mereka. Abaya tradisional menutupi tubuh secara sempurna dari atas hingga ujung kaki. Sementara di Riyadh, selain memakai abaya, banyak wanita yang menutup wajah mereka dari nonmahram dengan burqa atau niqab (cadar).

Seperti aspek penerimaan serta pemakluman individu terhadap unit-unit kultural yang dimiliki masing-masing etnis, sejatinya abaya dan niqabpun dapat dimaknai sama dan diterima layaknya sebuah pernyataan budaya dalam balutan simbol agama yang berakar dari hukum Islam. Maka cadar tidak bisa dipisahkan dari akar hukum Islam yang mewajibkannya.

\section{Teori Tindakan Sosial: Max Waber}

Sebagai pendekatan penelitian untuk melihat perilaku etnis Arab yang bermukim di kampung Almunawar khususnya komunitas wanita Arab yang mengenakan niqab di Palembang, dalam interaksinya dengan individu-individu dalam komunitasnya maupun di luar komunitas mereka (lokal), sehingga dalam penelitian ini digunakan pendekatan atau Teori Tindakan Sosial dari Weber.

Bagi Weber, jelas bahwa tindakan manusia pada dasarnya bermakna, melibatkan penafsiran, berpikir, dan kesengajaan. Unsur yang lahir dari definisinya bahwa tindakan sosial sebagai semua perilaku manusia ketika dan sejauh individu memberikan suatu makna subjektif terhadap perilaku tersebut (Mulyana, 2004).

Perilaku etnis Arab yang banyak bermukim di kampung Almunawar Palembang khususnya wanita Arab yang menggunakan abaya dan niqab pun tidak lepas dari tarikan tindakan sosial. Tindakan mereka diduga dimaknai oleh individuindividu diluar komunitasnya maupun dalam komunitas mereka sendiri. Karena itu tindakan mereka diduga mempertimbangkan perilaku orang lain berdasarkan orientasi penampilan yang mereka kenakan.

\section{Teori Fenomenologi: Schutz}

Schutz menyebut manusia yang berperilaku tersebut sebagai "aktor" ketika seseorang melihat atau mendengar apa yang dikatakan atau diperbuat aktor, dia akan memahami (understanding) makna dari tindakan tersebut. Dalam dunia sosial hal demikian disebut sebagai sebuah "realitas interpretatif". Bagi Schutz, tugas utama analisis fenomenologis adalah merekonstruksi dunia kehidupan manusia "sebenarnya" dalam bentuk yang mereka alami sendiri (Kuswarno, 2009).

Wanita bercadar merupakan aktor yang sarat akan realitas interpretatif, dikarenakan penampilannya yang menonjol jika terjun ke dalam masyarakat sekitar atau lebih besar lagi masyarakat Palembang pada umumnya.

Dalam konteks fenomenologis, wanita Arab bercadar adalah aktor yang melakukan tindakan sosial (bergaul, belanja, mengantar anak sekolah, pengajian) bersama aktor lainnya sehingga memiliki kesamaan dan kebersamaan dalam ikatan intersubjektif. Para aktor tersebut juga dapat dilihat dari kondisi yang akan menggambarkan diri mereka sendiri terhadap "masa yang akan datang dan harapannya" ataupun alasan "masa lalu yang menentukan mereka untuk bercadar".

\section{Teori Interaksi Simbolik: Mead}

Dalam teori interaksi simbolik Mead, berpandangan bahwa perilaku manusia pada dasarnya adalah produk dari interpretasi mereka atas dunia di sekeliling mereka, jadi tidak mengakui bahwa perilaku itu dipelajari atau ditentukan (Mulyana, 2006).

Teori ini sejalan dengan penelitian yang penulis lakukan, mengenai simbol komunikasi wanita Arab yang bermukim di kampung Almunawar di Palembang. Di mana pandangan interaksi simbolik membantu menjelaskan bagaimana wanita Arab yang mengenakan cadar memandang dirinya sendiri maupun pandangan orang lain terhadap dirinya.

Penulis beranggapan bahwa wanita Arab dengan atribut niqab yang menyertainya adalah juga manusia yang aktif dan dinamis yang memiliki kehendak bebas dalam menafsirkan simbol-simbol di lingkungannya. 


\section{Teori Dramaturgis: Erving Goffman}

Perilaku manusia bersifat dramatik ini dijelaskan dalam teori Dramaturgis Goffman. Mahzab Dramaturgis telah memperlakukan interaksi sosial sebagai suatu "drama" secara kiasan, yang dapat melengkapi perspektif psikologi-sosial untuk menganalisis perilaku manusia. Goffman memakai analog drama dan teater, hal itulah yang menjadikannya sebagai seorang dramaturgis (Mulyana, 2006).

Etnisitas menjadi persona Goffman, kemudian model-model Goffman tentang presentasi diri dan ritual interaksi cukup memadai untuk menguraikan perilaku budaya wanita Arab yang mengenakan cadar tersebut.

\section{METODE PENELITIAN}

Penelitian ini menggunakan metode kualitatif, dengan pendekatan fenomenologi. Studi fenomenologi berupaya untuk menjelaskan makna pengalaman hidup sejumlah orang tentang suatu konsep atau gejala, yang dalam penelitian ini wanita Arab bercadar, termasuk di dalamnya tentang konsep diri atau pandangan hidup mereka sendiri (Kuswarno, 2009). Subjek penelitian ini adalah wanita Arab yang menggunakan cadar di kampung Almunawar Palembang. Objek penelitian ini adalah pengelolaan kesan lewat simbol verbal dan nonverbal serta interaksi yang dilakukan. Akan diuraikan dalam bentuk komunikasi yang dilakukan secara internal ataupun eksternal oleh komunitas wanita Arab yang mengenakan cadar di Palembang. Sampel dilakukan dengan cara purposif sebanyak 11 orang. Adapun data tentang informan tersaji dalam tabel 1.

Dalam penelitian kualitatif metode yang biasa dimanfaatkan adalah wawancara, pengamatan, dan pemanfaatan dokumen, yang bertujuan untuk menelaah dan memahami sikap, pandangan, perasaan, dan perilaku individu atau sekelompok orang. Penggunaan berbagai metode ini sering disebut triangulasi, dimaksudkan agar penulis memperoleh pemahaman yang komprehensif (holistik) mengenai fenomena yang diteliti.

Tabel 1

Identitas Informan Penelitian

\begin{tabular}{|c|c|c|c|}
\hline No & Nama & Usia & Pekerjaan \\
\hline 1 & AS & 30 & Ustazah dan berdagang \\
\hline 2 & JSA & 29 & Mengajar dan berdagang \\
\hline 3 & FSA & 20 & Mengajar \\
\hline 4 & $\mathrm{Mg}$ & 27 & Ibu Rumah Tangga \\
\hline 5 & $\mathrm{AB}$ & 18 & Pelajar di madras \\
\hline 6 & MA & 30 & Ustazah \\
\hline 7 & Hsn & 20 & Pelajar di madras \\
\hline 8 & ZS & 25 & Ibu Rumah Tangga \\
\hline 9 & AS & 26 & Ibu Rumah Tangga \\
\hline 10 & $\mathrm{~V}$ & 21 & Pelajar di madras \\
\hline 11 & SBS & 22 & Ibu Rumah Tangga \\
\hline
\end{tabular}

Sumber: hasil penelitian 


\section{HASIL PENELITIAN}

DAN PEMBAHASAN

\section{Konstruksi Makna Cadar sebagai Kewajiban}

Penempatan konstruksi makna cadar sebagai kewajiban di nomor satu, dikarenakan penulis menemukan kecenderungan jawaban dari semua informan penelitian yang meyakini bahwa cadar adalah wajib. Terlepas bahwa ada yang berawal pemaknaan sebagai pakaian tradisi, namun selanjutnya setelah mereka berinteraksi dan mengetahui hukum cadar maka secara umum, informan penelitian ini mengonstruksi cadar sebagai kewajiban yang menjadi dasar pemaknaan cadar bagi mereka sendiri.

Salah satu yang memaknai sebagai kewajiban melalui proses belajar dan pergaulan dengan komunitas wanita Arab adalah V. Inilah ungkapan $\mathrm{V}$ dalam wawancara terbuka.

"Pertama kali tahu cadar itu baru setelah habis menikah, dari temen-temen suami karena suami ustad, dan rata-rata temen suami yang ustaz itu pake cadar, sampai istri habib Umar pun doain "insyallah ente nanti pake cadar" kakak jawab "amin". Dan insyallah pake cadar ini juga bukan paksaan, tapi emang mau karena kito udah tahu hukumnya, karena itu kewajiban menutup aurat. Segala sesuatu itu pasti ada resikonya mau dak mau harus ditanggung resikonyo" (wawancara dengan V, 5 Januari 2011).

\section{Konstruksi Makna Cadar sebagai Pernyataan Karakter Diri dan "Pelindung" Diri}

Pakaian merupakan simbol dari kepribadian, seperti halnya yang diungkapkan Liliweri bahwa pakaian menyatakan pada orang lain sesuatu mengenai identitas mereka yang unik. Semua informan peneliti sepakat bahwa cadar adalah pakaian yang wajib sebagai hukum Islam dan bukan budaya Arab (Liliweri, 2009).

Cadar sendiri pun mereka maknai sebagai pakaian yang menjaga diri dari fitnah, dan umumnya mereka merasa lebih terjaga dan nyaman dengan mengenakan cadar, seperti yang diungkapkan ZS: "rasonyo lebih dihormati bae, bukan minta hormati makmano tu nah ye (rasanya lebih dihormati saja, bukan minta dihormati)"(wawancara dengan ZS, 5 Januari 2011).

\section{Konstruksi Makna Cadar Berawal Sebagai Tradisi Keluarga}

Dari sepuluh informan dalam penelitian ini terdapat satu orang yang berdasarkan uraian mereka, awalnya memahami cadar sebagai pakaian warisan turun-temurun dari keluarga, karena semua perempuan dalam anggota keluarga tersebut menggunakan cadar. AB kemudian mulai menguraikan pengalamannya, berikut ini:

"dari kecik dipondoke, dipondok itu diwajibkan make cadar mun keluar make cadar, ummi dengan kakak make cadar, masih kecik waktu itu dak tau hukumnyo apo" (dari kecil masuk pesantren, dipesantren itu diwajibkan menggunakan cadar jika keluar). Ummi dan kakak menggunakan cadar, waktu itu masih kecil belum tahu hukumnya apa" (wawancara dengan AB, 7 Januari 2011).

Untuk menggambarkan konstruksi makna cadar bagi mereka sendiri, penulis menggambarkannya dalam model seperti pada gambar 1 .

Keterangan gambar dapat dijelaskan sebagai berikut: semua informan penelitian ini memiliki kesadaran menganggap bahwa cadar adalah kewajiban muslimah, berakardari pengetahuan akan hukum hijab melalui surat AlAhzab ayat 59. Pengetahuan inilah yang mendorong mereka untuk bertindak merubah diri dari berpakaian longgar menjadi tertutup sama sekali. Cadar merupakan pakaian yang tidak asing bagi mereka, karena nenek moyang mereka sendiri yang pernah tinggal di Palembang juga dulunya menggunakan cadar, namun gairah untuk menuntut ilmu dan mencari pengetahuan Islam jugalah yang memotivasi mereka dalam bertindak memutuskan mengenakan cadar. 


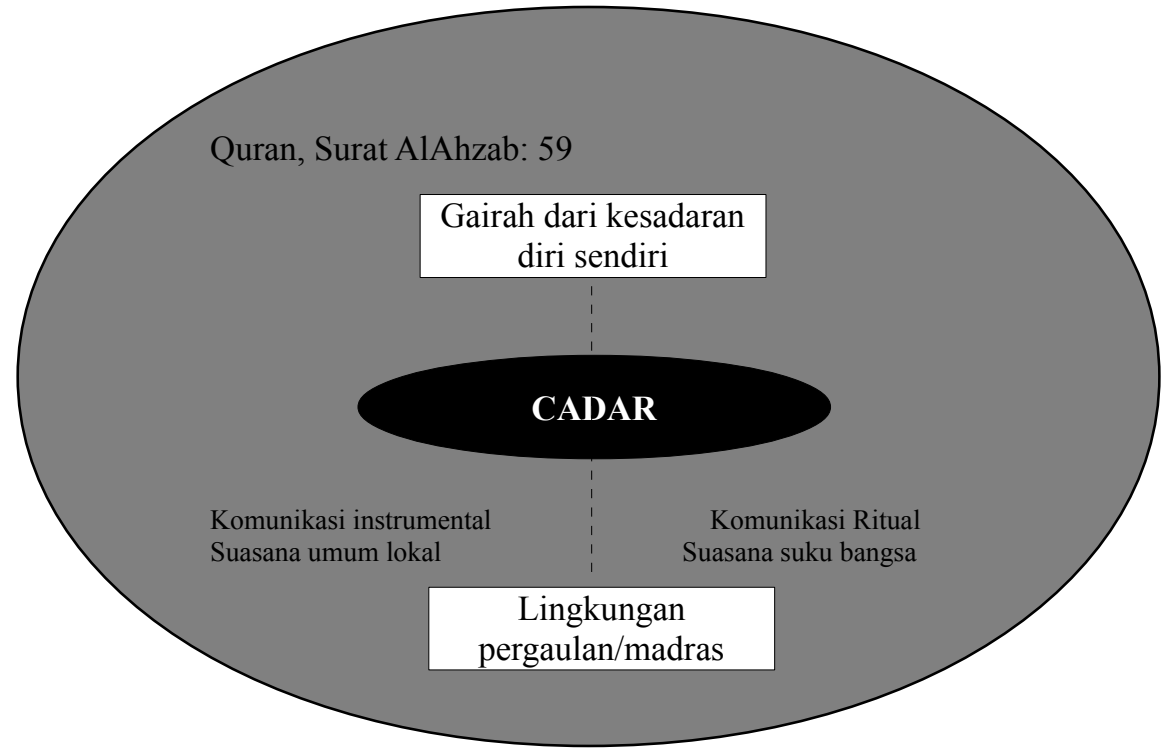

Sumber: Dikelola dari hasil Penelitian, 2011

\section{Gambar 1 \\ Konstruksi Makna Cadar bagi Wanita Arab Bercadar}

Lebih lanjut peranan, komunikasi instrumental dalam suasana kesukuan yang bertujuan menginformasikan, mengajar, mendorong, mengubah sikap dan keyakinan, dan mengubah perilaku atau menggerakkan tindakan dan juga menghibur yaitu lewat kehadiran seorang Hababa Nur dari Hadramaut. Hadramaut sendiri adalah "kampung halaman" bagi warga Arab di Palembang, merupakan fakta lain yang memotivasi mereka secara situasional dalam memaknai cadar.

Makna cadar menjadi kuat karena mereka selalu berkomunikasi dan berkumpul dalam lingkungan yang terkondisi dengan pakaian cadar maupun dalam suasana umum lokal. Dengan kondisi seperti demikian secara legowo mereka menerima bahwa cadar adalah pakaian yang tak lazim di Indonesia.

\section{Impression Management Wanita Arab Bercadar \\ Pengelolaan Kesan Wanita Arab Bercadar melalui Simbol Verbal}

Tidak ditemukan perbedaan penggunaan bahasa verbal di antara komunitas wanita Arab khususnya yang mengenakan cadar dengan masyarakat melayu Palembang.

Akan tetapi, ketika di dalam komunitas, sulit untuk dipisahkan wanita Arab yang mengenakan cadar atau tidak. Perbedaan dengan jelas dapat dilihat lewat nasab (marga). Dalam penelitian ini komunikasi verbal diidentifikasi melalui tuturantuturan, secara terbuka mereka mengakui tidak ada bahasa-bahasa khusus ketika berkumpul dalam komunitas mereka sendiri. Hanya saja ketika penulis melakukan pengamatan dan berperan serta dalam aktivitas rutin mereka, komunikasi verbal yang berlangsung sangat dinamis dalam artian penggunaan bahasa Palembang dan Arab bisa terjadi dominan dalam waktu bersamaan.

\section{Pengelolaan Kesan Wanita Arab Bercadar melalui Simbol nonverbal}

Ada tiga kondisi pengelolaan kesan yang dilakukan subjek penelitian melalui model-model berikut: Model pertama memperlihatkan simbol atau komunikasi nonverbal (gambar 2); Model kedua memperlihatkan gambaran, impression subjek penelitian lewat isyarat dan gerakan tubuh (gambar 3); Selanjutnya, lewat nada suara dapat dilihat dalam gambar 4 . 


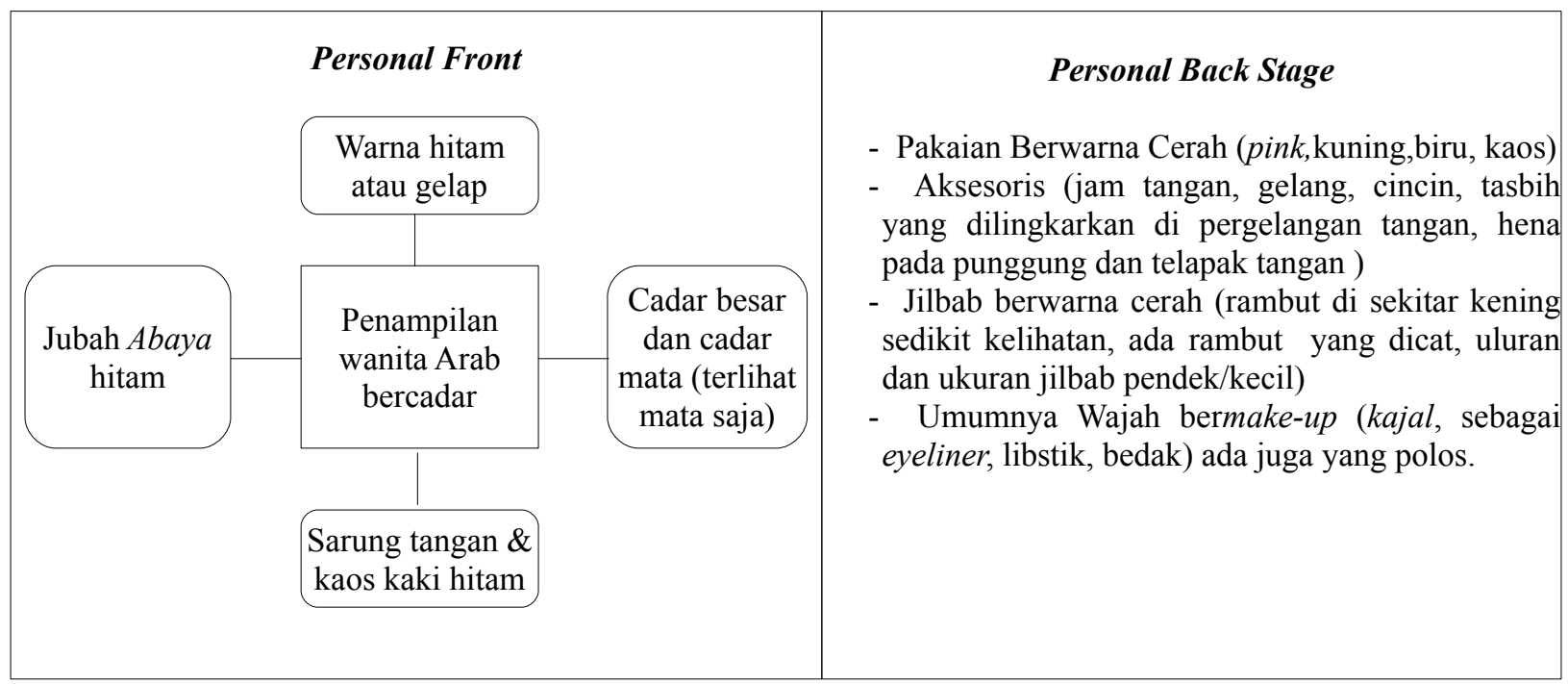

Sumber: Dikelola dari hasil pengamatan penelitian tanggal 28 Februari 2011

Gambar 2

Pengelolaan Simbol Nonverbal Wanita Arab Bercadar melalui Penampilan

\section{Wanita Arab/bercadar}

Kategori Usia Dan Hubungan Interpersonal

Teman/kenalan/anak-anak

Keluarga/teman dekat dan kerabat

Nenek-nenek(wanita usia lanjut)

Hababa(Ulama wanita/ustazah)
Perilaku Bersalaman/Berjabat Tangan

Bersalaman namun setelahnya masing-masing mencium telapak tangannya sendiri

Bersalaman kemudian mencium telapak tangan sendiri, mencium pipi kanan kiri, mengadu hidung pada sisi kanan dan kiri

Mencium punggung dan telapak tangan dua kali

Sumber: dikelola dari hasil pengamatan penelitian, 24-28 Februari dan 8-10 Maret 2011

\section{Gambar 3}

Perilaku Bersalaman/Berjabat Tangan Wanita Arab Bercadar dalam Pertemuan dengan Komunitas Mereka 


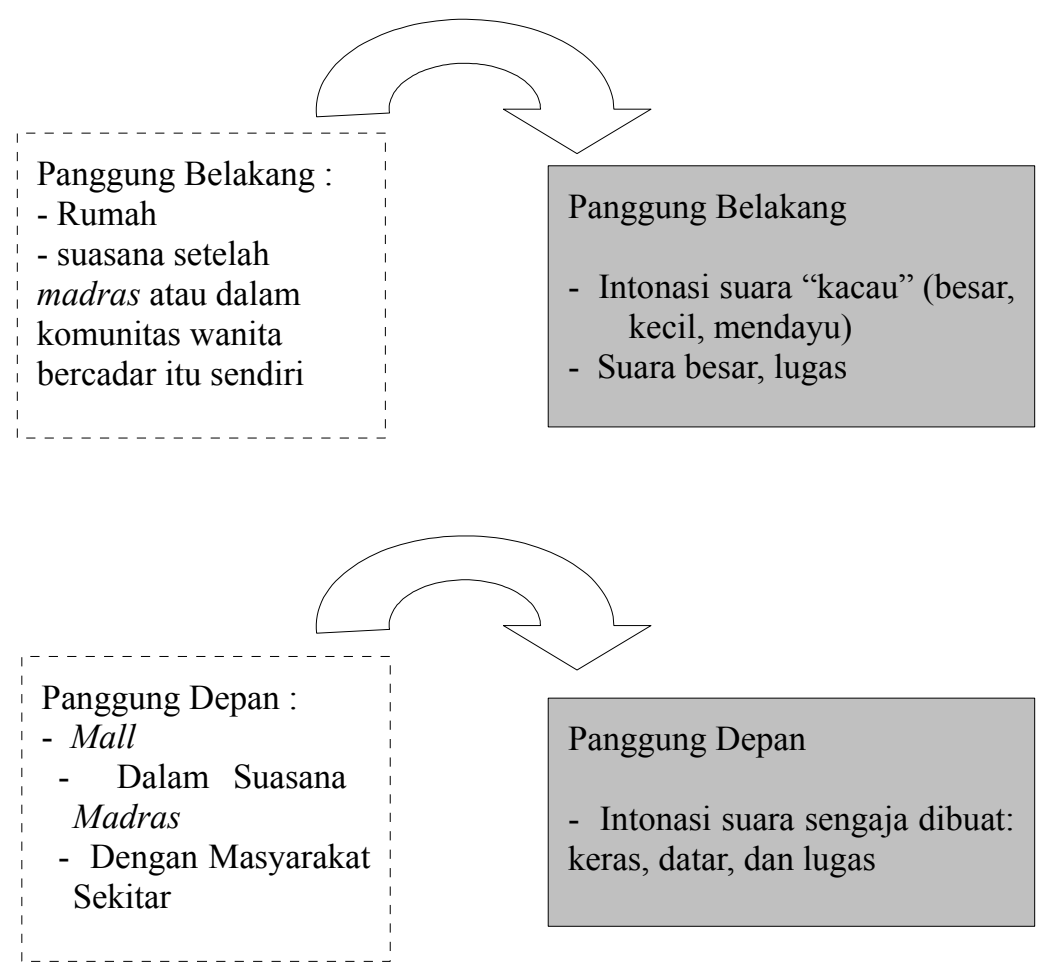

Sumber: Dikelola dari hasil Penelitian, 2011

Ket : Bahwa suara dimaknai sebagai aurat, layaknya wajah yang mereka cadari begitupun suara

\section{Gambar 4 \\ Pengelolaan Kesan melalui Nada Suara}

\section{Dinamika Komunikasi Wanita Arab Bercadar}

Bagaimana dinamika komunikasi wanita Arab yang mengenakan cadar dapat digolongkan sebagai kebutuhan, dorongan/ impuls, namun bukan tuntunan budaya atau tuntunan peran. Komunikasi yang berlangsung dalam komunitasnya dapat dibagi menjadi dua peristiwa, yaitu (1) peristiwa ketika wanita Arab bercadar berada dalam komunitasnya baik sesama wanita keturunan Arab yang tidak mengenakan cadar maupun aktivitas sesama mereka yang mengenakan cadar. (2) aktivitas wanita Arab bercadar di lingkungan tempat tinggal atau di luar aktivitas madras, majelis Burda, dan perayaan hari-hari besar seperti Maulid yang bertepatan saat penelitian ini berlangsung.

Suasana dalam madras, majelis Burda, dan perayaan hari besar atau Maulid yang bertepatan dengan waktu penelitian ini berlangsung dianggap sebagai panggung belakang. Karena apa yang ditampilkan layaknya pertemuan atau perkumpulan perempuan. Pada umumnya, mereka bebas mengenakan nada intonasi suara lembut atau kecil bahkan berteriak dan tertawa terbahak.

Di samping itu pakaian abaya yang dikenakan ketika berkumpulpun bisa dilepas, dengan penampilan pakaian lapisan seperti gamis bercorak cerah atau pakaian potongan atasan dan bawahan dengan berwarna terang. Ketika mereka di madras, mereka akan menyiapkan bilik papan atau pembatas yang memang sudah disediakan di madras tersebut, untuk membuat hijab antara ustaz dan mereka. Mengejutkan bagi penulis, dalam pengamatan penulis mereka belajar qitab dengan serius namun dengan penampilan yang begitu cair, mereka melonggarkan jilbab atau bahkan melepasnya, namun tetap fokus dengan pertanyaan yang sesekali dilontarkan ustaz. 
Penulis memperhatikan ekspresi mata mereka, umumnya mereka memiliki mata yang indah dan alis yang tebal teratur, dua orang penulis lihat menggunakan softlens dengan alasan bahwa mata mereka memang minus. Penulis juga melihat mereka menggunakan atribut unik lainnya. Memang tidak semua mengenakannya tapi hena, dan kajal banyak mereka kenakan.

Perbedaan bahasa verbal yang mereka kenakan hanya berkisar antara dua bahasa yang digunakan, yaitu bahasa Indonesia ketika mereka bertanya dengan ustaz atau menjadi pembicara dalam acara besar keagamaan, dan bahasa Palembang yang sesekali dilengkapi dengan bahasa Arab ketika berkumpul dalam komunitas mereka sendiri. Bahasa verbal yang sering pula penulis dengar adalah bahasa bernuansa agama, sering sekali mereka dalam setiap obrolan mengucapkan "insyalloh", "masyalloh", astgfirullah", "labaiq".

Mereka mengucapakan " $R$ " sedikit berbeda dengan orang Palembang perkotaan pada umumnya, kalimat yang memiliki rangkaian huruf "R", akan terucap samar ketika keluar dari mulut mereka dalam aktivitas bicara. Namun jika penulis meminta mereka menyebut huruf " $R$ " tanpa dirangkai dengan huruf-huruf lain, maka penulis mendengar ucapan huruf " $R$ " yang jelas dan lantang. Beberapa dari mereka tidak banyak bicara, hanya banyak tersenyum. Namun tidak sedikit yang riang gembira dan bersuara keras dan suka mengunyah permen karet.

Komunikasi verbal maupun nonverbal memiliki dua lapisan, yaitu ketika mereka berkomunikasi dengan wanita Arab bercadar yang berusia muda atau sebaya dan dengan wanita Arab bercadar yang berusia tua atau dipanggil ummi dan ustazah-ustazah yang umumnya berusia 30an. Ketika dengan wanita Arab baik bercadar atau tidak yang berusia tua dapat dikatakan nenek-nenek, mereka mencium punggung tangan dan telapak tangan dua kali, begitu pula dengan ustazah-ustazah, perilaku ini dimaksudkan untuk menghormati dan "mengambil" berkah usia yang bermanfaat menurut mereka. Suara mereka juga lebih rendah dan membungkuk jika sejajar dengan tinggi ummi yang dihormati ini. Kemudian mereka akan merangkul dan mencium pipi kanan dan kiri atau mengadu hidung pada kedua sisinya.

Berbeda dengan komunikasi verbal dan nonverbal yang ditunjukkan saat dengan teman-teman sebaya, umumnya wanita Arab bercadar ini lebih akrab dengan sesama mereka yang mengenakan cadar, sekalipun dalam madras atau perkumpulan mereka juga akrab dengan wanita-wanita keturunan Arab lainnya. Ketika V (inisial informan) yang datang bersama saya terlambat, dan bingung mencari tempat duduk. V disuruh duduk di depan di tempat wanita-wanita Arab bercadar, sementara penulis tidak ditawari, namun untuk keperluan penelitian, dengan menghiraukan ketidakberkenanan tuan rumah penulis mengikuti $\mathrm{V}$ berkumpul dengan wanita bercadar tersebut. Situasi ini menunjukkan kepada penulis bahwa persamaan identitas sadar atau tidak, menanamkan persepsi yang menggeneralisasikan individu dalam komunitas tertentu, terbukti lewat perlakuan orang lain yang menggiring $\mathrm{V}$ (sekalipun bukan orang Arab namun bercadar) untuk duduk bersama komunitasnya.

Selain itu ketika bersama dengan wanita Arab bercadar yang memiliki usia sebaya atau lebih muda, mereka cenderung lebih cair. Nada suara mereka lebih tidak terkendali, dari lembut, menjadi keras, dan berteriak. Panggilan-panggilan nama juga sesuka hati mereka, penulis bahkan melihat ada kesan sengaja mereka memanggil dengan panggilan yang paling lucu dari potongan nama rekan mereka masingmasing, misalnya Jasmine dipanggil Mimin, Fatimah dipanggil atim, Masturo dipanggil OA. Namun sekali lagi tidak semuanya seperti itu, karena tetap saja dalam panggung belakang ini wanita Arab bercadar memiliki kemampuan untuk menciptakan kesan yang baik di mata rekan-rekannya. Panggung belakang ini penuh dengan corak komunikasi yang cair dan mengejutkan seperti yang telah penulis uraiakan di atas. Interaksi yang berlangsung antara sesama wanita Arab yang mengenakan cadar ini dibangun oleh 
suatu simbol atau lambang dengan makna tersendiri.

Sementara di panggung depan yaitu ketika mereka berada dalam ruang-ruang sosial dan berinteraksi dengan lingkungan masyarakat sekitar. Pada kasus wanita bercadar ini berinteraksi dengan masyarakat sekitar kampung Arab, terbagi atas dua penampilan: (1) Mereka mengenakan cadar besar panjang yang menutup wajah mereka; (2) Mengenakan cadar mata, yang memperlihatkan kedua mata mereka. Kegunaan cadar mata pada dasarnya apabila mereka berada dalam suasana yang sedikit redup seperti di dalam pasar tradisional atau sedang mengendarai kendaraaan, baik mobil atau motor.

Namun jika di angkot biasanya menggunakan cadar besar, walaupun hampir jarang mereka menggunakan angkot. Hanya ada satu informan yang mengaku pernah naik angkot. Wanita Arab bercadar ini jikapun harus menggunakan kendaraan umum mereka menggunakan becak, adakalanya penulis terkikih saat melihat abang becak yang memanggil Jasmine untuk naik becaknya, padahal sebenarnya yang sedang dipanggilnya itu adalah Adilla. Ini menunjukkan bahwa interaksi wanita Arab bercadar sekalipun tak tampak wajah dapat berlangsung dengan baik, terbukti dengan abang becak yang tahu nama mereka walaupun tidak mengetahui orangnya.

Pada panggung depan yang paling kentara pengelolaan nada suara. Ketika berinteraksi di luar baik dengan perempuan terlebih laki-laki, mereka sangat sedikit bicara, jika diperlukan mereka akan berbicara dengan nada suara keras, datar, dan lantang tapi bukan berteriak. Namun jika tidak mengharuskan mereka bicara, seperti sebuah pertanyaan yang mengandung jawaban "ya" dan "tidak" maka mereka lebih menggunakan isyarat tubuh, seperti menggeleng atau melambai kaku telapak tangan mereka yang terbalut dengan sarung tangan hitam.

Suara lantang dan cepat ini juga mereka tunjukkan ketika sedang belajar di madras, yang ustaznya laki-laki. Sesekali ustaz mengajukan pertanyaan atau mereka menjawab dan bertanya. Suara mereka terdengar tegas dan lantang, tidak gugup atau terbata-bata, dan lembut. Dari pengamatan penulis, ketika mereka di panggung depan mereka cenderung menggunakan cadar panjang, seperti ketika penulis secara tidak sengaja bertemu AZ (inisial informan) di mall, penulis melihat AZ membuka cadarnya namun membelakangi sisi yang memungkinkan dilihat orang lain, saat penulis dekati dengan gesit AZ menutup wajahnya kembali, dan ketika penulis panggil namanya, AZ membuka cadarnya dan tersenyum sambil mengulurkan tangan untuk bersalaman.

Aktivitas bersalaman selalu berlangsung baik di panggung depan maupun di panggung belakang saat wanita Arab bercadar ini bertemu rekan dekat atau yang sekedar kenal-kenal biasa seperti penulis, sejauh individu yang diajak bersalaman itu perempuan. Penulis bahkan merasa tersanjung tatkala masuk dalam komunitas tersebut dan mereka tidak sungkan untuk memulai mengulurkan tangan bersalaman.

Dalam pandangan interaksi simbolik, sebagaimana ditegaskan Blumer, proses sosial dalam kehidupan kelompoklah yang menciptakan dan menegakkan aturanaturan, bukan aturan-aturan yang menciptakan dan menegakkan kehidupan kelompok. Dalam konteks ini makna dikonstruksikan dalam proses interaksi, dan proses tersebut bukanlah suatu medium yang netral yang memungkinkan kekuatankekuatan sosial memainkan perannya, melainkan justru merupakan substansi sebenarnya dari organisasi sosial dan kekuatan sosial.

Sementara simbol verbal dan simbol nonverbal yang mereka gunakan merupakan produk interaksi sosial dalam komunitas warga Arab di Palembang. Produk interaksi sosial ini sejalan dengan premis kedua dari paradigma interaksi simbolik, di mana makna tidak melekat pada objek, melainkan dinegosiasikan melalui penggunaan bahasa. Negosiasi ini dimungkinkan karena manusia mampu menamai segala sesuatu, bukan hanya objek fisik, tindakan atau peristiwa (bahkan tanpa kehadiran objek fisik, tindakan atau peristiwa itu), namun juga gagasan yang abstrak. 


\section{QS. AlAhzab ayat 59}

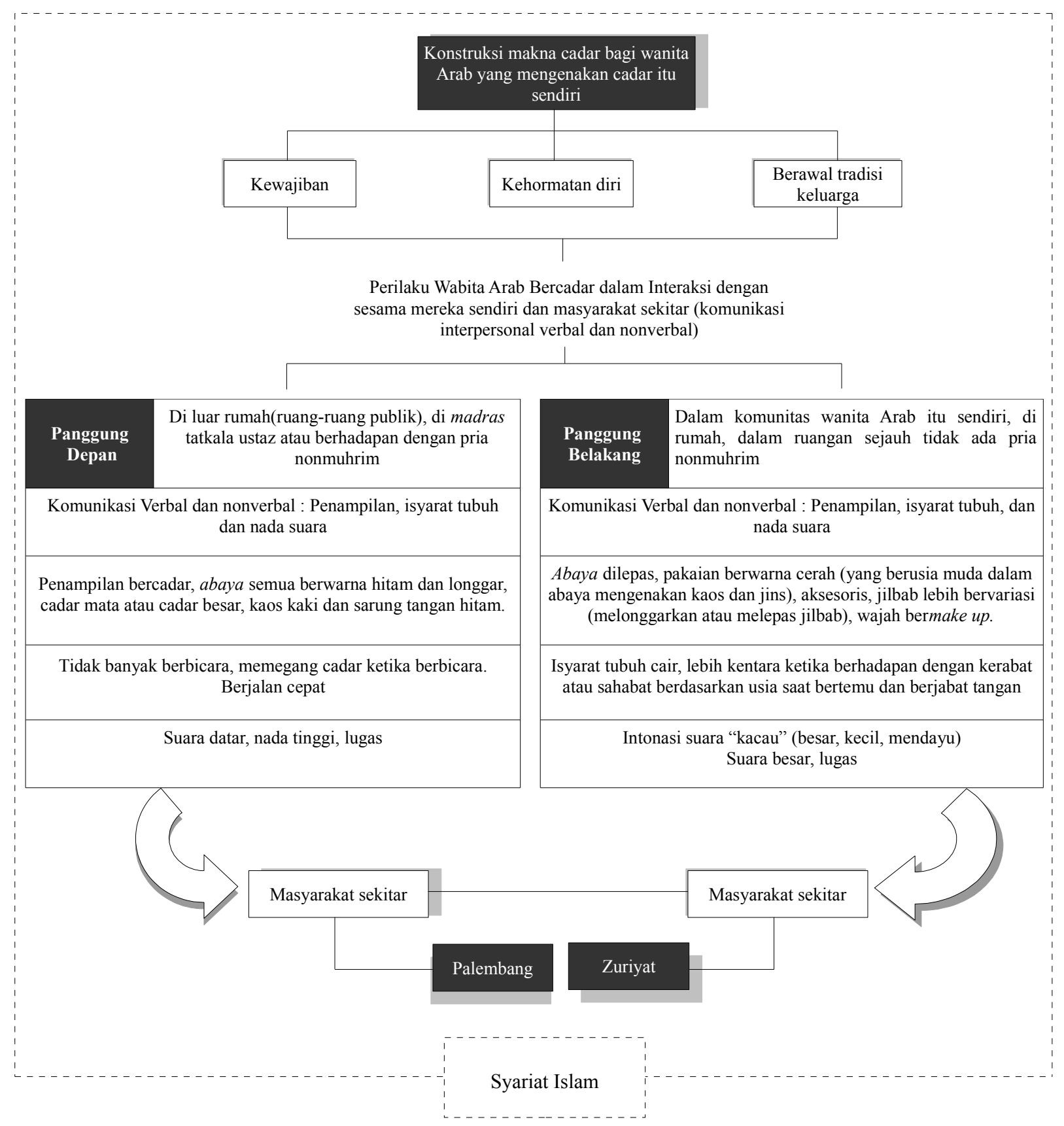

Sumber: Dikelola dari hasil Penelitian, 2011

Gambar 5

Dinamika Komunikasi Wanita Arab Bercadar di Palembang 
Akan tetapi, nama atau simbol yang digunakan untuk menandai objek, tindakan peristiwa atau gagasan itu bersifat arbitrer (sembarang). Artinya apa saja yang bisa dijadikan simbol dan karena itu tidak ada hubungan logis antara nama atau simbol dengan objek yang dirujuknya, karena makna besifat subjektif dan sangat cair. Secara keseluruhan dari hasil penelitian ini, penulis konfigurasikan dalam bentuk model. Model tersebut begitu kompleks karena di lapangan penulis menemukan banyak nuansa-nuansa di luar asumsi awal penelitian ini, seperti nuansa etnis yang muncul dalam komunitas mereka sendiri sesama warga keturunan Arab. Pada gambar 5 hasil penelitian yang penulis sebut sebagai konstruksi hasil penelitian.

Schutz menyebut manusia yang berperilaku tersebut sebagai "aktor" ketika seseorang melihat atau mendengar apa yang dikatakan atau diperbuat aktor, dia akan memahami (understanding) makna dari tindakan tersebut. Dalam dunia sosial hal demikian disebut sebagai sebuah "realitas interpretatif". Hal ini terlihat dari selalu ada embel-embel kewajiban dalam kategori yang penulis klasifikasikan, artinya alasan atau dalil mereka mengonstruksi makna cadar tidak terlepas dari hukum Islam yaitu AlAhzab ayat 59, sebagai awal alasan mereka berperilaku dan bertindak. Karena itulah QS AlAhzab ayat 59 penulis hadirkan dalam model tersebut. Melalui pemaknaan cadar bagi mereka sendiri inilah yang juga mengemukakan penjelasan dari salah satu konsep diri (self), aku (I), daku (me) interaksi simbolik, yaitu bagaimana individu memandang dirinya seperti itu pula orang lain memandangnya. Karena itu pulalah penelitian ini mau tidak mau memperlihatkan dinamika komunikasi yang terjadi, baik dalam interaksi dan perilaku komunikasi wanita keturunan Arab yang mengenakan cadar ini sendiri maupun dengan masyarakat sekitar. Dalam interaksi tersebut berlangsung sebuah proses pengelolaan kesan yang terjadi sekaligus mewarnai komunikasi mereka. Pengelolaan kesan ini tidak lain termotivasi karena satu alasan yaitu syariat Islam.

Pengelolaan kesan pada panggung depan sengaja mereka bentuk dengan kesadaran akan hukum Islam yang mereka yakini. Pada panggung depan situasional seperti berhadapan dengan laki-laki non muhrim atau ustaz manakala belajar di madras, akan mereka kelola semua potensi komunikasi verbal dan nonverbal seperti penampilan dengan menggunakan cadar utuh dan suara. Sementara pada panggung belakang suasana lebih cair dan dapat dikatakan "kacau" mereka dapat mengekspresikan dan mengaktifkan semua isyarat verbal dan nonverbal. Interaksi mereka dengan sesama komunitas mereka berlangsung cair tanpa pengelolaan kesan, suara bisa menjadi lembut dan mendayu tapi sesaat bisa juga keras dengan intonasi yang tinggi. Penampilan pun bisa sangat "kacau" ketika di panggung belakang, artinya mereka bisa membuka apapun aurat yang boleh diperlihatkan sejauh dalam ruangan tersebut berisi komunitas mereka sendiri yaitu wanita bercadar.

Lain lagi polanya ketika mereka berinteraksi dengan masyarakat sekitar khususnya pada warga yang perempuan yang tidak bercadar. Mereka akan lebih cair tidak mengelola suara akan tetapi masih membatasi penampilan, artinya sekali pun berada di ruangan yang kesemuanya perempuan, dengan masyarakat sekitar mereka masih menggunakan abaya hanya cadar yang mereka tanggalkan.

Pada panggung belakang inilah terlihat suasana yang lebih kental dalam faktor keturunan, ketika mereka berkumpul dengan sesama warga Arab maka wanita Arab yang memiliki marga ini lebih suka dikenal sebagai zuriyat. Sementara wanita Arab yang tidak memiliki marga, menganggap mereka sebagai keturunan dari keluarga Arab saja. Lain halnya saat interaksi berlangsung dalam ruang-ruang sosial yang memungkinkan bercampurnya orang Palembang Melayu dan keturuna Arab, seperti di majelis. Wanita Arab ini menganggap diri sebagai orang Palembang. Tidak ada penggunaan bahasa yang berbeda begitu juga perilaku dan kebiasaan yang berbeda dengan orang Palembang Melayu. Bahasa verbal menjadi berbeda saat berada dalam komunitas wanita Arab bercadar atau wanita warga Arab yang 
tidak menggunakan cadar, istilah-istilah Arab akan mereka gunakan, nuansa-nuansa Islam berlangsung kental terutama ketika berkaitan dengan perilaku-perilaku sunnah Rasul.

Pada akhirnya semua yang mereka kelola, semua tindakan yang mereka lakukan dan kesadaran diri tentang makna cadar yang mereka konstruksi sendiri terbentuk oleh satu motivasi yaitu syariat hukum Islam.

\section{PENUTUP}

\section{Simpulan}

Penelitian ini relevan dengan pemilihan paradigma subjektivis, karena mampu mengungkap persoalan secara holistik dan mengangkat fenomena yang cenderung tersembunyi. Pendekatan kualitatif dalam penelitian ini memberikan laporan yang kaya dan rinci mengenai pengalaman wanita keturunan Arab yang mengenakan cadar dalam mengonstruksi makna cadar dan dinamika impression management.

Wanita keturunan Arab yang mengenakan cadar, mengonstruksi makna cadar berdasarkan sudut pandang mereka terhadap hukum Islam yang mewajibkan cadar sebagai busana wanita muslimah dan busana kehormatan muslimah. Wanita keturunan Arab memelihara identitas nasab mereka dengan hanya menikahi laki-laki bernasab zuriyat juga artinya yang memiliki garis keturunan langsung dengan Nabi Muhammad SAW. Bahasa dan struktur identitas budaya Arab sudah bercampur dengan adat masyarakat Palembang. Interaksi yang berlangsung di antara wanita Arab bercadar itu sendiri berlangsung cair dan longgar yaitu simbol yang menandai objek sangat arbiter ketika bertemu dengan orang tua, kerabat dekat, atau kenalan.

\section{Saran}

Penulis menyarankan pada akademisi ilmu sosial, instansi pemerintah, dan LSM yang bergerak dibidang perlindungan perempuan atau aktivis-aktivis perempuan, untuk melanjutkan penelitian ini lebih mendalam. Dengan harapan banyaknya penelitian memunculkan publikasi dan kebijakan yang mampu memberi informasi yang komprehensif dan "bijaksana" bagi masyarakat yang masih memandang "ketidaklaziman" wanita bercadar. Jika cadar di Indonesia dianggap budaya Arab maka perlu dikaji ulang oleh pihak yang berkompeten dibidang syariat Islam dalam hal ini adalah pemerintah. Agar meminimalisir munculnya stereotip yang berlebihan takkala menjumpai wanita bercadar di ruang sosial.

\section{DAFTAR PUSTAKA}

\section{Buku :}

Kuswarno, Engkus. (2009). Fenomenologi. Metode Penelitian Komunikasi; konsepsi, pedoman, dan contoh penelitian. Bandung:Widya Padjadjaran.

Liliweri, Alo. (2003). Dasar-dasar Komunikasi Antarbudaya. Yogyakarta: Pustaka Belajar. . (2003). Makna Budaya dalam Komunikasi Antarbudaya. Yogyakarta: LkiS.

Mulyana, Deddy. (2006). Metode Penelitian Kualitatif: Paradigma Baru Ilmu Komunikasi dan Ilmu Sosial Lainnya. Bandung: PT. Remaja Rosdakarya.

Mulyana, Deddy dan Solatun. (2008). Metode Penelitian Komunikasi: Contohcontoh Penelitian Kualitatif Dengan Pendekatan Praktis. Bandung: PT. Remaja Rosdakarya .

Mulyana, Deddy dan Jalaludin Rakhmat. (2009). Komunikasi Antarbudaya; Panduan Berkomunikasi Dengan Orang-Orang Berbeda Budaya. Bandung: PT. Remaja Rosdakarya .

\section{Sumber lainnya: Internet:}

Anonim. (2010). Larang Wanita Bercadar Mengemudi- Berita Liputan 6. Tersedia dalam <www.liputan6.com. $>$ Diakses pada tanggal 9 Januari 2011.

Anonim. (2010). Tersedia dalam $<$ www.islamic center al-Islam-pusat 
kajian Islam website $>$. Diakses pada tanggal 9 Januari 2011.

Mukhtar mai. (2008) In The Name of Honor.

Tersedia dalam

$<$ http://www.books.google.com>.

Diakses pada tanggal 11 Maret 2011 